\title{
Intestinal graft versus host disease
}

\author{
R L Bryan, G N Antonakopoulos, J Newman, D W Milligan
}

\begin{abstract}
An ileocolectomy specimen was examined from a patient with graft versus host disease (GvHD). In addition to the characteristic histological features of this condition, both the small and the large intestine showed extensive destruction of mucosal tissue with survival of clusters of enterochromaffin cells. This appearance has previously been described only in the large bowel. Endocrine cells seem to be less vulnerable to the effects of GvHD than epithelial cells, resulting in their being spared, which is not seen in other types of crypt destruction.
\end{abstract}

Graft versus host disease (GvHD) is a multisystem disorder principally affecting the skin and the gastrointestinal tract, and seen most frequently after bone marrow transplantation. In acute GvHD, typically occurring three to four weeks after transplantation, the histological changes seen in the gastrointestinal tract include apoptosis of individual crypt cells, proceeding to "exploding crypts" with minimal associated inflammation. In severe cases total mucosal denudation occurs. ${ }^{1-3}$ Lampert et al noted that there was selective sparing of endocrine cells in large bowel biopsy specimens from such areas. ${ }^{4}$

We have recently had the opportunity of examining an ileocolectomy specimen removed for GvHD and this showed similar endocrine cell preservation in both the large and small intestine.

\begin{tabular}{|c|}
\hline $\begin{array}{l}\text { Department of } \\
\text { Histopathology, } \\
\text { East Birmingham } \\
\text { Hospital, Bordesley } \\
\text { Green East, } \\
\text { Birmingham B9 5ST } \\
\text { R L Bryan, } \\
\text { G N Antonakopoulos, } \\
\text { J Newman }\end{array}$ \\
\hline $\begin{array}{l}\text { Department of } \\
\text { Haematology } \\
\text { D W Milligan }\end{array}$ \\
\hline $\begin{array}{l}\text { Correspondence to: } \\
\text { Dr R L Bryan }\end{array}$ \\
\hline $\begin{array}{l}\text { Accepted for publication } \\
21 \text { March } 1991\end{array}$ \\
\hline
\end{tabular}

Figure 1 Section of ileum showing apoptosis of . glandular epithelial cells (haematoxylin and eosin).

\section{Case report}

A 39 year old man presented with $T$ cell acute lymphoblastic leukaemia. Nine months after diagnosis and while in first remission, he received a bone marrow graft from his HLA haplo-identical sister. The graft was not $T$ cell depleted and GvHD prophylaxis was with methotrexate and cyclosporin A. By day 17 the blood count indicated good engraftment but grade I-II skin GvHD developed. This responded to methyl prednisolone. Ten days later he developed colicky abdominal pain and bloody diarrhoea. Sigmoidoscopy showed severe proctitis with patchy mucosal loss. An air contrast barium enema showed extensive disease of the large bowel. Despite treatment with antilymphocyte globulin and methyl prednisolone he developed signs of peritonism and underwent an ileocolectomy and ileostomy. His condition deteriorated and he died one week later.

\section{Pathology}

The resected specimen consisted of $45 \mathrm{~cm}$ of ileum and $85 \mathrm{~cm}$ of caecum and colon with an $8 \mathrm{~cm}$ appendix. There was extensive mucosal ulceration with a surface exudate along the entire length of the specimen, except for occasional surviving mucosal islands. The distal $15 \mathrm{~cm}$ was thickened. The features were reminiscent of severe active ulcerative colitis.

Light microscopical examination showed extensive mucosal ulceration in both the small and the large intestine. Islands of intact mucosa contained disrupted crypts, often with hyperchromatic and atypical epithelial cell nuclei. There were scattered apoptotic epith-

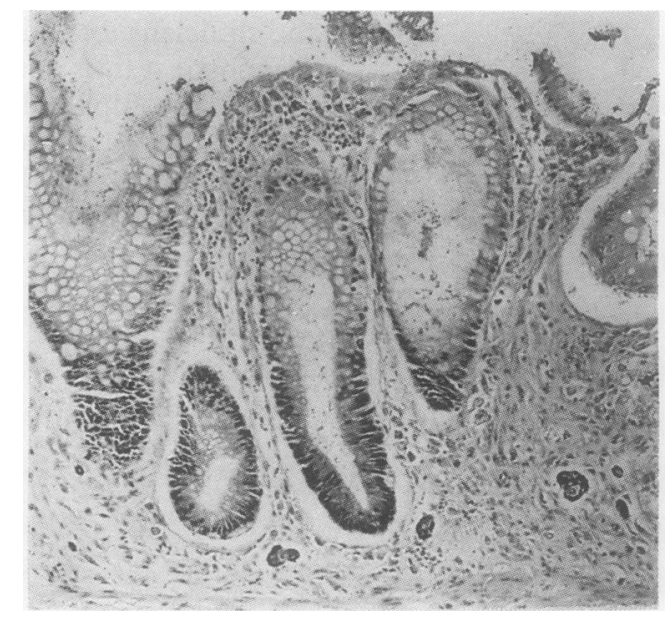

Figure 2 Section of ileum showing loss of mucosal glands but sparing of endocrine cells (Pascual). 
Figure 3 Two cells from a surviving mucosal cluster. In the smaller cell the granules are densecored while in the larger cell they are bigger and of medium electron density.

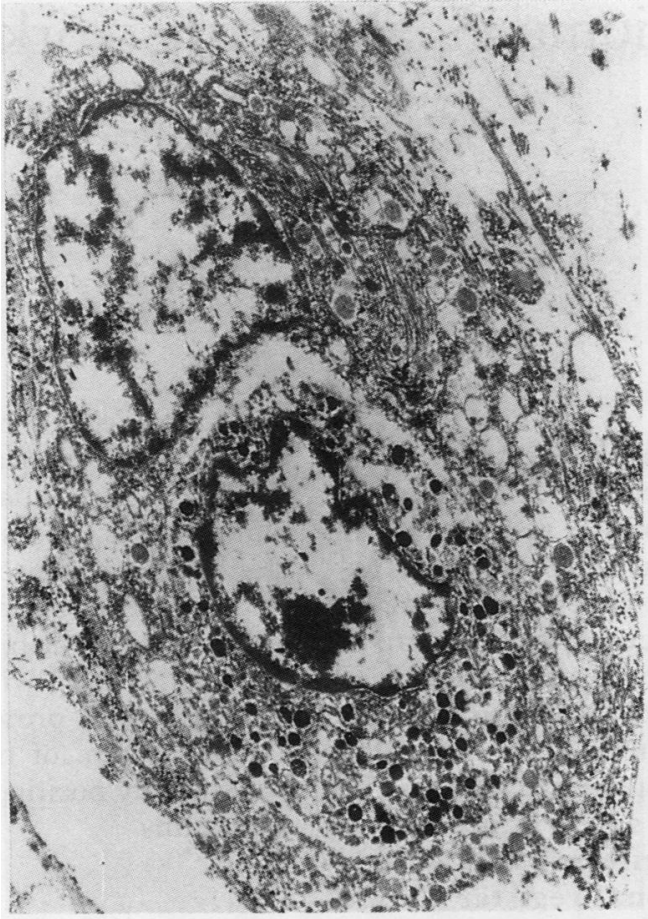

elial cells and occasional "exploding crypts" characteristic of GvHD (fig 1). These surviving islands were separated by large zones of apparently featureless granulation tissue which completely replaced the mucosa. Close examination of these ulcerated areas in both the small and the large intestine as well as the appendix showed scattered nests of cells with basophilic cytoplasm and occasional similar groups in areas of surviving mucosa, apparently at sites of single crypt loss (fig 2 ). The cells forming these clusters showed cytoplasmic positivity with argentaffin and argyrophil stains and for neurone specific enolase. Electron microscopical examination confirmed the enterochromaffin nature of these cells; they contained abundant, often dense-cored cytoplasmic granules (fig 3).

\section{Discussion}

Acute GvHD is characterised by apoptosis of glandular epithelial cells and "exploding crypts" (cell debris enveloped in spaces at the base or side of crypts). ${ }^{56}$ The diagnosis can only be made at least 20 days after conditioning chemotherapy and radiotherapy, once the histological effects of these have resolved. ${ }^{78}$ More severe disease results in total mucosal denudation with a less specific appearance. In our case the complete histological spectrum was seen throughout the resected specimen.

The observation of sparing of endocrine cells in GvHD was first reported by Lampert et $a l^{4}$ in a series of colonic biopsy specimens.
In our case this feature was present in both the small and the large intestine and in the appendix.

The pathogenesis of GvHD is controversial, but the primary event is probably cytotoxic $\mathrm{T}$ cell mediated crypt cell lysis. ${ }^{6}$ Further damage, culminating in mucosal denudation, may also follow bacterial superinfection of the intestinal mucosa because of immune deficiency resulting from donor-host lymphoid cell interactions. ${ }^{69}$ Alternatively, further mucosal damage may result from the release of toxic cytokines by host lymphoid cells following allogeneic reactions with donor lymphocytes. ${ }^{10}$ This may then result in aberrant expression of class II major histocompatability complex antigen by epithelial cells $^{11}$ and subsequent destruction by cytotoxic T cells. ${ }^{12}$

Intestinal endocrine cells may be less susceptible than glandular epithelial cells to some or all of these insults, a feature not seen in other types of gland destruction such as inflammatory bowel disease and ischaemic colitis. This feature may possibly be related to their increased differentiation, although even these cells are destroyed in the most severe areas of GvHD.

We are grateful to $\mathrm{Mr}$ A Campbell for technical assistance and to Mrs V Griffiths for typing the manuscript.

1 Barrett AJ. Graft-versus-host disease: a review. J Roy Soc Med 1987;80:368-73.

2 Talbot IC, Price AB. Biopsy pathology in colorectal disease. London: Chapman and Hall, 1987: 364-5.

3 Pavli P, Doe WF. The alimentary tract in disorders of the immune system. In: Whitehead R, ed. Gastrointestinal and oesophageal pathology Edinburgh: Churchill Livingstone, oesophageal path
1989: 191-3.

4 Lampert IA, Thorpe P, van Noorden S, Marsh J, Goldman JM, Gordon-Smith EL, Evans DJ. Selective sparing of enterochromaffin cells in graft versus host disease affecting the colonic mucosa. Histopathology 1985;9:875-86.

5 Sale GE, Shulman HM, McDonald GB, Thomas ED Gastrointestinal graft-versus-host disease in man. A clinicopathologic study of the rectal biopsy. Am J Surg Pathol 1979;3:291-9.

6 McDonald GB, Shulman HM, Sullivan KM, Spencer GD. Intestinal and hepatic complications of human bone marrow transplantation. Gastroenterology 1986;90: marrow

7 Epstein RJ, McDonald GB, Sale GB, Shulman HM, Thomas ED. The diagnostic accuracy of the rectal biopsy in acute graft-versus-host disease: a prospective study of thirteen patients. Gastroenterology 1980;78:764-71.

8 Snover DC, Weisdorf SA, Vercellotti GM, et al. A histopathologic study of gastric and small intestinal graftversus-host disease following allogeneic bone marrow transplantation. Hum Pathol 1985;16:387-92.

9 Beschorner WE, Yardley JH, Tutschka P, Santos G. Deficiency of intestinal immunity with graft-vs-host disease in humans. J Infect Dis 1981;144:38-46.

10 Grebe SC, Streilein JW. Graft-versus-host reactions: a review. Adv Immunol 1976;22:119-221.

11 Cert-Bensussan N, Quaroni A, Kurnick JT, Bhan AK Intraepithelial lymphocytes modulate Ia expression by Intraepithelial lymphocytes modulate Ia expression by

12 Londei M, Lamb JR, Bottazzo GF, Feldmann M. Epithelial cells expressing aberrant $\mathrm{MHC}$ class II determinants can present antigen to cloned human $\mathrm{T}$ cells. Nature 1984;312:639-41. 